\title{
IMPLEMENTASI MODEL KADERISASI MAHASISWA UNTUK MEMBANGUN KARAKTER UNGGUL DI MASJID SALMAN
}

\author{
Anis Najmunnisa, Cecep Darmawan, Siti Nurbayani K \\ Universitas Pendidikan Indonesia \\ Jl. Dr.Setiabudi 229 Bandung 40154, Jawa Barat, Indonesia \\ Email: anisnajm8@gmail.com
}

\begin{abstract}
Abstrak Generasi muda merupakan generasi yang membutuhkan figur yang baik untuk menjadi teladan dalam bersikap dan berperilaku. Namun, keadaan moral mengalami kemerosotan, sehingga menyebabkan terjadinya perilaku menyimpang dalam kehidupan sosial. Dalam hal ini, perlu adanya dasar pembinaan karakter, agar generasi muda tidak mudah terjerumus ke dalam hal-hal negatif, salah satunya melalui generasi muda terdidik mahasisiwa. Insan muda yang terdidik menjadi harapan agar menjadi benteng dan menularkan karakter unggul pada masyarakat. Dalam hal ini, Masjid kampus Salman ITB, memiliki tujuan untuk mendidik mahasiswa agar tidak mudah terpengaruh ke dalam hal-hal yang negatif, salah satunya melalui kegiatan rutin program kaderisasi. Kaderisasi Salman yang bertujuan untuk mengkader mahasiswa agar dapat mewariskan nilai-nilai yang terkandung di Salman. Penelitian ini menggunakan pendekatan kualitatif yang menekankan kepada gambaran mengenai kegiatan kaderisasi Salman dalam membangun kualitas karakter mahasiswa yang unggul. Pengumpulan data dilakukan dengan teknik observasi, wawancara mendalam, dan studi dokumentasi. Peneliti melakukan kegiatan wawancara mendalam dengan beberapa informan. Hasil penelitian menunjukkan bahwa; pertama, melalui kegiatan kaderisasi Salman, mahasiswa dilatih untuk berpikir cara menyelesaikan permasalahan, tidak hanya menyelesaikannya namun harus memiliki visi jangka panjang. Kedua, model yang diterapkan dalam kegiatan kaderisasi Salman menggunakan model pembergaulan, dengan cara mengenalkan mahasiswa dengan sesamanya, memperkenalkannya dengan tokoh-tokoh inspiratif, agar dapat menularkan semangatnya, dan memberikan peran yang berupa tanggung jawab untuk dilaksanakan. Ketiga, upaya memonitoring peserta kaderisasi melalui kegiatan usroh (keluarga/mentoring) bagi mahasiswa yang berada di Bandung, dan memberikan buku saku untuk dilaporkan perkembangannya bagi mahasiswa di luar Bandung. Keempat, kendala yang dihadapi dalam kegiatan kaderisasi Salman diantaranya kurangnya koordinasi antarpanitia, kurangnya sarana dan prasarana, dan perubahan cuaca yang sulit di prediksi. Adapun solusi yang dilakukan diantaranya memperbaiki kembali koordinasi antarpanitia, memperbaiki dan mengganti sarana dan prasarana yang rusak, dan panitia serta peserta diingatkan agar lebih sigap saat menghadapi perubahan cuaca.
\end{abstract}

Kata kunci: $\quad$ kaderisasi, karakter unggul, mahasiswa, model.

\section{PENDAHULUAN}

Masyarakat Indonesia dikenal sebagai masyarakat yang memiliki karakter yang memiliki budi pekerti yang baik, gemah ripah, memiliki semangat gotong royong yang tinggi, serta toleransi terhadap keberagamannya. Bangsa Indonesia merupakan bangsa yang memiliki masyarakat majemuk secara sosial dan budaya yang terus berkembang dari waktu ke waktu. Didukung pula oleh kondisi geografisnya yang berada di lintasan khatulistiwa, yang memiliki kekayaan alam yang melimpah, subur, dan makmur. Seharusnya dengan kondisi sosial budaya dan kekayaan alam yang melimpah, masyarakatnya dapat merasakan kehidupan yang makmur dan sejahtera.

Namun, kondisi sekarang menunjukkan hal yang berbeda antara kekayaan dan kemakmuran masyarakatnya. Kini masyarakat Indonesia sedang mengalami krisis multidimensional mulai dari kesejahteraan sosial, budaya, ekonomi, hukum, dan politik yang menaungi kehidupan sosial. Krisis masalah sosial yang masih hangat terjadi diantaranya penyimpangan sosial, korupsi yang merajalela, dan kasus politik yang makin bergejolak, sehingga menimbulkan keresahan masyarakat akibat dari situasi sosial yang mengalami kekacauan. Berbagai masalah yang terjadi menimbulkan pertanyaan, apa yang sedang terjadi, berbagai perspektif hipotesis melihat indikasi permasalahan.

Saat salah satu pemimpin ibu kota tidak sengaja memancing SARA bagi masyarakat Indonesia yang mayoritas muslim, menimbulkan reaksi yang luar biasa bagi kelompok masyarakat mayoritas yang selama ini kurang memiliki kekuatan untuk menghadapi kelompok minoritas yang memangku 
jabatan. Ditengah krisis masalah masyarakat yang meresahkan, harapan masyarakat bertumpu pada pemimpin pemerintah sebagai pemangku kebijakan, untuk dapat ikut andil menengahi dan memberikan jalan keluar serta rasa aman bagi masyarakatnya. Namun, yang terjadi, sebagian dari pemimpin pemerintah menyalahi amanah yang sedang diembannya, dengan cara memperkaya diri dari jabatan yang didudukinya. Korupsi masih menjadi salah satu masalah sosial yang masih mengakar kuat dan membudaya sejak zaman kolonialisme.

Fenomena yang masyarakat rasakan, tidak berbanding lurus dengan harapan mengenai kesejahteraan individu dan sosial. Perilaku intoleransi, sinisme, kemerosotan ekonomi, dan ketidakpercayaan pada pemimpin, kerap menjadi persoalan nyata, pada tabiat sikap masyarakat Indonesia yang memiliki karakter unggul dalam berbagai bidang. Fenomena ini menjadi sangat ironi, mengenai permasalahan sosial yang terjadi. Ketika perkembangan zaman makin dinamis dengan berbagai teknologinya, kita masih sibuk bergelut dengan sumber daya manusia yang idealnya menjadi solusi dan pembaharu untuk memecahkan persoalan. Menurut pandangan penulis, penyebab utama permasalahannya adalah mengenai karakter. Rusaknya kondisi moral dan perilaku generasi muda yang hancur, menyebabkan timbulnya masalahmasalah lain. Melalui permasalahan generasi muda seperti tawuran pelajar, seks bebas, alkoholisme, dan sebagainya, akan berujung pada rusaknya karakter yang menjadi akut dan parah.

Permasalahan ini perlu segera dibenahi bersama, salah satunya melalui pembenahan karakter, penguatan kembali terhadap penanaman moral dalam berperilaku, menghargai sesama dan keberagaman tanpa menodai SARA, serta memiliki bekal nilai-nilai agama yang melekat dalam diri, sehingga mampu menyeleraskan nilai luhur agama dan persatuan kebhinekaan bangsa yang beraneka ragam. Perubahan ini bisa dibina salah satunya melalui mahasiswa sebagai agent of change. Salah satu pendidikan nonformal yang dapat diterapkan untuk membangun karakter cerdas dan beretika melalui masjid kampus sebagai wadah yang dapat menaungi generasi muda, khususnya mahasiswa.

Dalam hal ini, peneliti menyoroti mengenai aktivitas kaderisasi masjid kampus yang dapat melahirkan calon-calon generasi pemimpin yang memiliki kualitas handal dalam segi sikap dan intelektual. Adapun kegiatan kaderisasi masjid kampus ini bersifat terbuka, untuk mahasiswa di seluruh nusantara untuk mengikuti rangkaian kegiatan kaderisasi. Pada era sekarang sudah tidak asing lagi bagaimana masjid kampus dapat memberikan pemahaman serta pembinaan untuk mendidik mahasiswa menjadi insan yang siap mewarisi peradaban. Dalam perspektif Al-Qur'an, signifikansi masjid melakukan pembinaan didasarkan pada penjelasan Al-Qur'an yang mengingatkan agar manusia hendaklah takut kepada Allah SWT, orang-orang yang seandainya meninggalkan dibelakang mereka generasi yang lemah, yang mereka khawatir terhadap (kesejahteraan) mereka (QS. 4: 9).

Dalam kajian sosiologis, pembinaan masjid kampus membentuk dapat kemampuan untuk melakukan interaksi sosial yang positif sehingga mampu menempatkan posisi diri dan lingkungannya. Tak hanya itu, kaderisasi masjid kampus Salman berusaha menggali kelebihan dan potensi yang ada dalam diri masing-masing anggota. Adapun penelitian yang dilakukan oleh Firdaus (2011) mengenai "Revitalisasi Peran Masjid dalam Pengembangan Kepemimpinan Mahasiswa (studi multi kasus masjid kampus UPI, ITB, dan UIN Bandung) menyatakan bahwa: "Pendidikan sebagai usaha untuk membina dan mengembangkan pribadi manusia dari aspek rohaniah dan jasmaniah harus berlangsung secara bertahap/berproses. Melalui proses tersebut, pendidikan dimaksudkan untuk mengarahkan anak didik (manusia) kepada titik optimal kemampuannya yaitu terbentuknya kepribadian yang utuh sebagai makhluk individual dan sosial serta hamba Alloh yang mengabdikan diri kepada-Nya".

Sejalan dengan hasil penelitian tersebut, bahwa pendidikan tidak hanya untuk mendapatkan nilai yang berupa angka-angka, namun sebagai upaya pembinaan untuk mengembangkan nilai-nilai kehidupan, sehingga menjadi kepribadian yang melekat dalam diri individu.

Dalam jurnal Masjid Kampus sebagai Media Komunikasi Aktivis Dakwah dalam Pembentukan Karakter Mahasiswa (Qaharudin Tahir, Hafied Cangar, dan Basyir Syam jurnal vol 3. No. 3 penelitian di masjid kampus Universitas Hasanudin Makasar dan UIN Alauddin) dalam hasil penelitiannya menunjukkan bahwa aktivis dakwah dan penggunaan masjid kampus sebagai media komunikasi berpengaruh secara simultan dan signifikan terhadap pembentukan karakter mahasiswa dan karakter mahasiswa yang terbentuk melalui aktivis dakwah yang menggunakan masjid sebagai media komunikasi adalah karakter pribadi, karakter ibadah, dan karakter sosial. Berkaitan dengan judul yang diangkat oleh penulis, mengenai kegiatan di masjid kampus, mahasiswa yang 
karakternya terbina dapat menuntun hidupnya baik masa sekarang atau pun masa depan dengan membawa perilaku-perilaku baik, yang akan mengakar kuat ke dalam karakternya hingga dapat menjadi perilaku sehari-hari.

Didukung pula oleh penelitian tesis Yudi Fachruddin mengangkat tentang fenomena majlis taklim. Berkembangnya kesadaran islam ditandai oleh maraknya pengajian-pengajian yang diselenggarakan, peserta pengajian kaum muda, seolah menguatkan pandangan orang-orang diperkotaan khususnya anak muda mengalami kekeringan nilai-nilai spiritual. Menurut Moeflich Hasbulloh, 2012 hlm. 55-57

Gerakan masjid kampus bermula dari masjid salman ITB di Bandung. Gerakannya merebak ke masjid kampus lainnya terutama di Jawa. Aktivis masjid salman membuat program-program yang memenuhi kebutuhan keagamaan di setiap level dari anak-anak dibuat program PAS (Pembinaan AnakAnak Salman), remaja dan pemuda serta mahasiswa khususnya yang aktif dalam kegiatan masjid dibentuk organisasi Keluarga Remaja Islam Salman (Karisma) dengan menyelenggarakan program Studi Islam Intensif (SII), selain itu juga dibuat program mentoring bagi remaja, diselenggarakan setiap minggu pagi, pada program ibu-ibu, masjid salman menyediakan program Kursus Kesejahteraan Rumah Tangga (KKR). Program yang sukses lainnya, program Latihan Mujtahid Dakwah (LMD), sebagai program kaderisasi untuk memperluas dakwah Islam di kampus-kampus dan jaringan antarmahasiswa islam secara luas.

Hasil penelitian tersebut, membahas mengenai awal pergerakan masjid kampus yang bermual dari masjid salman, yang menjadi acuan peneliti untuk melihat lebih jauh perkembangan kaderisasi yang telah dilaksanakan, dan dapat bertahan melalui pasang surutnya kondisi masjid kampus sebagai penanam nilai karakter unggul. Berdasarkan penelitian-penelitian terdahulu yang berkaitan dengan judul yang diangkat, menunjukkan bahwa hasil pendidikan yang dilaksanakan oleh masjid kampus terhadap mahasiswa menghasilkan karakter-karakter yang unggul sehingga menjadi pribadi yang berkualitas.

Dalam proses kaderisasi ini, pihak masjid kampus ingin menentukan potensi kader, agar dapat diarahkan sesuai dengan minat dan bakat yang dimilikinya. Masjid salman memiliki visi yang mengusung mengenai peradaban, adapun nilai-nilai yang ingin ditanamkan untuk membangun karakter unggul, mengacu pada empat sifat Rasulullah saw yaitu berbudi cerminan nilai spiritual, berilmu cerminan nilai intelektual, bergaul cerminan nilai sosial, dan berkarya cerminan nilai profesional. Melalui empat karakter inilah, diharapkan proses kegiatan kaderisasi mampu membangun karakterkarakter unggul yang akan mencerminkan masyarakat peradaban.

Karakter berbudi yang ingin ditanamkan dalam visi salman, mengacu pada pembinaan jiwa, melalui budi seseorang telah menemukan kunci hidup yang sesungguhnya, hari-harinya penuh dengan hikmah, dan pintu-pintu kebaikan lain akan terbuka dalam hidupnya. Karakter berilmu yang ingin ditanamkan mengacu pada kecerdasan intelegensi, hal ini menimbulkan daya tarik tersendiri serta mudah baginya untuk dapat diikuti banyak orang karena kecerdasannya dalam menyikapi suatu hal dapat berbeda dengan yang lain. Karakter bergaul merupakan cerminan nilai sosial, para kader salman dapat berinteraksi dengan baik, toleransi, tidak egois terhadap orang lain, dan memiliki keluwesan menerima perubahan dan hal baru dengan tetap selektif untuk kemaslahatan. Dan karakter berkarya mengacu pada hasil minat dan bakat yang ada dalam diri individu masing-masing. Melalui karya, individu yang memiliki karakter unggul akan bermanfaat bagi orang banyak, memiliki dedikasi untuk kemaslahatan sosial melalui hakikat potensi yang diberikan oleh Alloh SWT.

Masjid merupakan wadah yang strategis dalam membina umat yang tangguh dan berkualitas. Sejalan dengan itu peran sentral masjid makin dituntut agar mampu menampung dan mengikuti segala perkembangan yang terjadi di dalam masyarakat dan lingkungannya melalui berbagai kegiatan yang dikemas oleh pembina dan pengurus masjid. Adapun masjid kampus yang akan dijadikan tempat penelitian adalah salah satu masjid terkenal di kota Bandung, yaitu masjid salman ITB. Oleh karena itu, peneliti tertarik mengkaji mengenai "Implementasi Model Kaderisasi Mahasiswa untuk Membangun Karakter Unggul di Masjid Salman ITB".

\section{STUDI LITERATUR}

Dalam Yudhit Ciphardian, 2010 Kader dalam bahasa Perancis, cadre, yang artinya elite (golongan atas yang terpilih dari terbaik karena terlatih). Dalam Suarsyif, 2009 Menurut Kamus Besar Bahasa Indonesia kaderisasi berarti proses, cara, perbuatan mendidik atau membentuk seseorang menjadi kader. Kader merupakan orang yang diharapkan akan memegang peranan penting di dalam pemerintahan, 
partai, ormas, dan sebagainya. Dalam kehidupan kampus, kaderisasi ini bertujuan untuk membentuk kader yang bisa menggerakkan organisasi, himpunan, ataupun kelompok dengan kepentingan masing-masing agar dapat terus berkembang.

Kaderisasi menurut islam diartikan sebagai usaha mempersiapkan calon-calon pemimpin hari esok yang tangguh dalam mempertahankan dan mengembangkan identitas khairu ummah, umat terbaik. Ini sesuai dengan seruan Allah dalam AlQur'an. Judul penelitian ini adalah Pelaksanaan Program Kaderisasi Mahasiswa untuk Membangun Karakter Unggul di Masjid Salman. Agar tidak terjadi salah penafsiran dalam judul tersebut, peneliti mengemukakan batasan penelitian berikut ini.

Kaderisasi adalah proses pendidikan yang direncanakan oleh suatu lembaga untuk menghasilkan kader calon penerus kekuasaan yang memiliki kualitas yang unggul. Seperti halnya Masjid Salman yang merupakan Masjid Kampus Institut Teknologi Bandung (ITB), memiliki kegiatan yang terus dilakukan untuk mencetak kader-kader pilihan terbaik dari mahasiswa yang sedang melanjutkan pendidikannya di Bandung, dari berbagai universitas. Bahkan, Masjid Salman akan mulai merintis membuka pendaftaran untuk calon kader dengan skala nasional.

Masjid Salman adalah suatu tempat atau wadah dimana didalamnya tidak hanya sebagai tempat ibadah saja, namun juga menyediakan fasilitas pendidikan, unit-unit organisasi untuk mahasiswa, yang tidak hanya berasal dari kampus ITB saja, namun banyak yang terlibat di luar kampus ITB, seperti UPI, UIN Bandung, UNPAD, UNPAS, dll. Kaderisasi kaitannya dengan penelitian ini adalah, kegiatan rutin yang dilakukan Salman dalam upaya mempersiapkan kader-kader mahasiswa yang memiliki kualitas karakter unggul, untuk siap menghadapi realita kehidupan, dengan cara melakukan yang terbaik dan berkarya. Kualitas karakter ini, salah satunya dibangun melalui pelatihan-pelatihan yang diadakan pada kegiatan Salman. Masjid Salman memiliki agenda kegiatan kaderisasi yang telah terkonsep dengan baik, melalui rangkaian kegiatan SSC dan LMD.

\section{METODE PENELITIAN}

Penelitian ini melihat bagaimana kegiatan kaderisasi mahasiswa di masjid kampus, dapat membangun karakter unggul mahasiswa. Dalam hal ini penelitian ini berfokus mengambil sampel secara bertujuan dari berbagai kampus. Variabel terikat pada penelitian ini adalah kegiatan kaderisasi mahasiswa di masjid kampus, dengan indikator melihat perkembangan karakter mahasiswa. Untuk variabel bebasnya berfokus pada pembangunan karakter yang indikatornya meliputi pendidikan masjid kampus. Jenis penelitian ini menggunakan observasi partisipan, wawancara, studi dokumentasi, dan studi literatur.

\section{HASIL DAN PEMBAHASAN}

Keberadaan masjid kampus tidak hanya berfungsi sebagai ritual ibadah sembahyang wajib yang dilakukan oleh muslim. Namun, sesuai dengan perkembangannya, masjid kampus menjadi salah satu wadah untuk mengembangkan pendidikan, sosial, dan bidang lainnya yang diharapkan dapat membantu permasalahan yang ada di masyarakat sekitar, melalui sentuhan agama. Bentuk dari macam-macam potensi yang dikembangkan dalam masjid kampus inilah, yang akan menjadi cikal bakal para kader yang akan mewarisi nilai masyarakat, untuk menjadi bagian dari pemimpin atau yang akan menyelesaikan permasalahan menuju kehidupan sosial yang lebih baik. Tak bisa dipungkiri, keberadaan masjid kampus sebagai wadah pendidikan dan pengembangan karakter religius, kurang diminati mahasiswa, pola hidup hedonisme dan acuh tak acuh terhadap keadaan sosial, membuat mahasiswa bersikap individualis.

Berdasarkan hasil penelitian Lazuardi, Moh Rizal mengenai Pembinaan Akhlak dalam Pendidikan Nonformal bagi Mahasiswa Universitas Muhammadiyah Surakarta mengemukakan bahwa:

Eksistensi pendidikan yang bernuansa akhlak mulia, menjadi sangat penting tidak hanya untuk membekalai mahasiswa dalam hal pengamalan nilainilai agama yang dianut, tetapi yang terpenting adalah mengantarkan peserta didik agar menjadi manusia yang berbudi pekerti luhur (berakhlak mulia). Pendidikan akhlak membawa nilai pokok untuk terwujudnya manusia yang memiliki akhlak mulia serta mampu mengamalkan ilmu dan keterampilan yang digelutinya dalam bentuk sikap dan perilaku tanpa meninggalkan nilai-nilai akhak mulia. Dalam hal ini, penulis melakukan penelitian pada mahasiswa UMS di Pesantren mahasiswa AlAusath. Penelitian ini merupakan penelitian lapangan (field research) dengan pendekatan kualitatif. Populasi dalam penelitian ini adalah seluruh elemen yang terlibat dalam proses pembinaan akhlak di pesantren Al-Ausath. Proses pembinaan akhlak secara umum tergolong cukup berjalan dengan baik, antara lain meliputi : pola pembiasaan 2-1 memberi ruang mahasiswa untuk 
belajar, beramal, dan berdawah sekaligus, metode pembinaan yang variatif menempuh segala metode yang memungkinkan seperti pengajaran, pembiasaan, keteladanan, islah, dan nasihat. Hasil pembinaan secara umum menunjukkan hasil yang positif dan memenuhi standar minimal akhlak seorang muslim meliputi akhlak kepada Allah, akhlak kepada sesama, dan akhlak kepada diri sendiri.

Hal tersebut sangat disayangkan, seiring dengan besarnya potensi sumber daya manusia yang dimiliki, bila karakter generasi muda tidak dimanfaatkan dengan baik dalam hal positif yang lebih bermanfaat. Dari adanya hal tersebut, sangat mengkhawatirkan, apabila generasi muda khususnya mahasiswa tidak memiliki karakter unggul dalam dirinya. Salah satu masjid kampus yang peduli dengan keadaan para generasi muda, yakni masjid kampus Institut Teknologi Bandung (ITB), dengan masjid Salmannya memiliki harapan besar, agar dapat merangkul generasi muda sebaik-baiknya, melalui program yang diadakan oleh yayasan pembina masjid dan staff jajarannya, agar dapat mencetak para kader generasi muda yang memiliki kualitas karakter unggul. Melalui jenjang-jenjang kaderisasi yang dilaksanakan Salman, memiliki tujuan-tujuan yang ingin dicapai, dalam membentuk karakter para kadernya.erdasarkan hasil temuan dan pembahasan diatas, dapat disimpulkan bahwa pelaksanaan program kaderisasi

\section{KESIMPULAN}

Berdasarkan hasil temuan dan pembahasan diatas, dapat disimpulkan bahwa pelaksanaan program kaderisasi Salman dapat membangun karakter unggul mahasiswa. Adapun peserta kaderisasi dilatih agar memiliki kualitas karakter unggul, melalui kegiatan Salman Spiritual Camp (SSC), Latihan Mujtahid Dakwah (LMD), dan kegiatan Usroh atau mentoring lanjutan. Adapun karakter unggul yang ingin ditanamkan Salman, mengacu pada empat sifat Rasulullah Saw, diantaranya siddiq, fathonah, tabligh, dan amanah. Pelaksanaan kegiatan kaderisasi Salman memiliki tujuan untuk mewariskan nilai-nilai agar dapat diteruskan oleh generasi penerus yang akan memimpin generasi selanjutnya.

\section{REFERENSI}

Ciphardian, Yudhit (2010, 6 April). Bukan Generasi Kepalang Tanggung.

KomkepSurabaya.[Online]dapatdiaksesdihttps://komk epsurabaya.wordpress.com/2010/04/06/bukangenerasi-kepalang tanggung/

Firdaus, Aep Sy. (2011). Revitalisasi Peran Masjid Dalam Pengembangan Kepemimpinan Mahasiswa

(Studi Multi Kasus di Masjid Kampus UPI, ITB, dan UIN Bandung ). S3 thesis, [Online]. Dapat diakses di http://repository.upi.edu/7886/.

Hasbullah, Moeflich. (2012). Sejarah Sosial Intelektual Islam di Indonesia. Bandung : Pustaka Setia.

Tahir, Qaharuddin, Hafied Cangara. (2014). Masjid Kampus sebagai Media Komunikasi Aktivi Dakwah dalam Pembentukan Karakter Mahasiswa. Vol.3 No.3 Juli-September 2014. [Online] dapat diaksesdihttp://journal.unhas.ac.id/index.php/kareba/ar ticle/view/588.. 